\title{
Challenges in public procurement before, during, and after the COVID- 19 crisis: Selected theses on a competency-based approach
}

\author{
Michael Eßig Christian von Deimling Andreas Glas
}

\begin{abstract}
This paper develops three theses on a competency-based approach during and after the COVID19 crisis. These theses are based on the following empirical findings: case insights into the procurement of protective gear in Germany, the supplier shortage, which was a problem even before the crisis, and a quantitative view on the extended supply chain challenges in public procurement, including the decreasing number of bidders and an overly narrow view on supply chain partners. A key finding is that while the COVID-19 crisis has uncovered the problems of public procurement, the root causes lie more deeply in public procurement capabilities. As a result, this paper promotes extended public buyer competencies based on a European Framework, evidence-based decision-making in public procurement and the use of digital technologies to improve the security of supplies.
\end{abstract}

\section{Re-thinking public procurement: Some thoughts made more urgent by the COVID-19 crisis}

The need to professionalize public procurement was recognized long before the crisis. In fact, the crisis hit public procurement entities while they were implementing professionalization measures. During the crisis, it has become clear that public procurement plays a strategically important role (e.g., securing the supply of medical equipment). The crisis has also clarified that the public has high expectations for the efficiency of public procurement activities (e.g., in terms of the medial presence of public procurement) that may help to ease or overcome the crisis. However, the crisis has also revealed fragile supply chains that are vulnerable to sudden and unexpected disruptions and deficits in public procurement. The need to professionalize public procurement now extends to a more thorough and resilient supply chain management. Moreover, as a measure of economic recovery, public procurement will certainly gain additional long-term importance to secure markets, drive their development and promote the emergence of new companies. Therefore, the role of public procurement as an instrument of market development and job security is drawing attention. In the future, the contribution of public procurement to a functioning community should be more strongly rewarded to make the service more attractive.

This article will report on three phenomena that have arisen in public procurement practice. First, it starts with the pandemic crisis of COVID-19. Second, data on bidding volumes and, in particular, about the number of bidders is evaluated. Third, the influence of public procurement on suppliers is examined by using a supply chain perspective. All three phenomena indicate that improvements can only be achieved if public procurement addresses more fundamental and underlying problems. As a contribution, this article argues that a competency-based approach has high potential for improving public procurement and proposes theses on how to develop competencies in the profession, the evaluation of evidence and technology. The theses are summarized and provide promising paths for future research. As a first step in the development of the competency-based theses for public procurement, the next sections provide insights into empirical phenomena. 


\subsection{Empirical findings I: Public procurement of protective gear}

During the COVID-19 pandemic, the need for protective equipment has risen enormously, with tenders for billions of protective masks being issued at short notice. At the same time, much of the protective equipment has so far been produced in Southeast Asia. For example, 75\% of simple surgical masks come from China. Moreover, in the face of global demand, the prices of what had been considered "cent items" have risen by up to $300 \%$. This is associated with challenges about how the demand can be economically covered by procurement measures. Süddeutsche Zeitung, a renowned German newspaper, has reported on the associated procurement problems in the following two articles: ${ }^{1}$

"So far, the German government has not succeeded in obtaining sufficient protective clothing, especially from China, where masks and other materials are produced in large quantities. Now the government wants to use 'the expertise of large companies' that do business with China, it is said in government circles. Companies like $V W$ are familiar with Chinese structures in a very different way, they know the supply chains and the purchasing chains'. [...] 'These companies bring their experience and contacts in foreign markets to organise purchasing and logistics for the government'. [...] The demand for protective clothing is so great that the federal government's purchasers are not yet able to keep up. Purchasing via the procurement offices of the Federal Ministry of Defence and the Federal Ministry of the Interior has started very slowly. This has not worked, according to the environment of Federal Minister of Health [...]. Only a fraction of the protective masks previously procured by the federal government had come through the procurement offices."

Subsequently, under the heading "Businesses can do better," another article from the same newspaper states:

"Civil servants and politicians should not phone around the world trying to get face masks or respirators. This will only waste valuable time. They should hand this task over to business. [...] Civil servants and politicians cannot just phone around the world and procure any goods. They lack the experience. [...] Governments and ministries have valuable skills that they are currently demonstrating. But they are not familiar with the world market for medical products. How could they? When politicians try to act as buyers, valuable time is lost in the fight against corona. [...] There are many experts in industrialized countries for the global procurement of all kinds of products. They sit in the companies."

According to these media reports, the perception of public procurement is as follows:

a) Political leadership and professional expertise in the contracting award entities and public authorities or ministries are mixed and evaluated without differentiation.

b) The public sector is denied the ability to procure at all.

c) Public procurement as a profession is negated.

\subsection{Empirical findings II: Supplier shortage even before the crisis}

There are currently only a few data sources available for the study of the awarding behavior of public purchasers. These include data retrieved from the online version of the "Supplement to the Official Journal" of the EU, dedicated to European public procurement (tenders electronic daily, TED). In principle, the ted database contains all notices of contracts to be awarded in the future (so-called "Contract Notices," CN) and contracts that have been awarded already (so-called

\footnotetext{
${ }_{1}^{1}$ See Translated quotes from https://sz.de/1.4866977 and https://sz.de/1.4867005, called up April 8th, 2020.
} 
"Contract Award Notices," CAN) above certain threshold values. ${ }^{2}$ Focusing on the available data for contract award notices (CAN), makes it possible to identify approximately 1.7 million CAN for all European member states (including associated member states such as Norway or Switzerland) for the period 2009 to 2018.

Since the enforcement of the European Public Procurement Directives (e.g., 2014/23/EU, 2014/24/EU, 2014/25/EU) in 2014, the number of published notices on awarded contracts (CAN) has been steadily increasing (cf. Figure 1). In 2017 and 2018 in particular, there were major leaps in the number of published CAN. Of the approximately 1.7 million notices on awarded contracts, about 237,000 notices (i.e., just under 14\%) were published by public contracting authorities in Germany. The positive trend of the number of published notices (see Figure 1) in Germany is similar to the numbers observed for all member states.

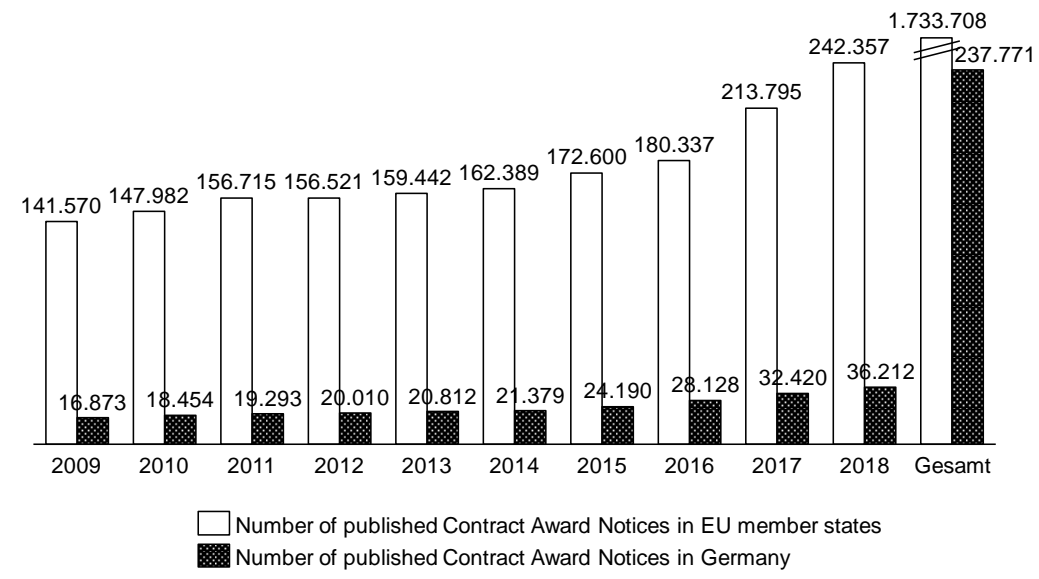

Figure 1: Number of CAN

The clearly positive trend in the number of CAN is also reflected in the procurement volume, although it is more volatile after 2017 (cf. Figure 2). The data demonstrate that currently only a fraction of the annual public procurement volume can be viewed and tracked via the ted data. For example, in Germany, of the estimated annual public procurement volume of approximately $€ 350$ billion [Eßig \& Schaupp, 2016] in 2017 and 2018, only values between $€ 45$ and $€ 48$ billion have been reported, which corresponds to a share of about $13 \%$ of the annual procurement volume. For the years 2017 and 2018, the average contract value (per contract award notice) would thus be between $€ 1.2$ and $€ 1.5$ million. $^{3}$

2 See TED data is published yearly and has an „open access policy“. The data is available via https://data.europa.eu/euodp/de/data/dataset/ted-csv and was called up on May 1st 2020.

${ }^{3}$ While there is little doubt, that data quality in the ted-database is in part questionable it is also the only open data platform that provides deeper insights into public procurement behaviour. For a more elaborated view on data quality limitations see Prier et al.(2018). 


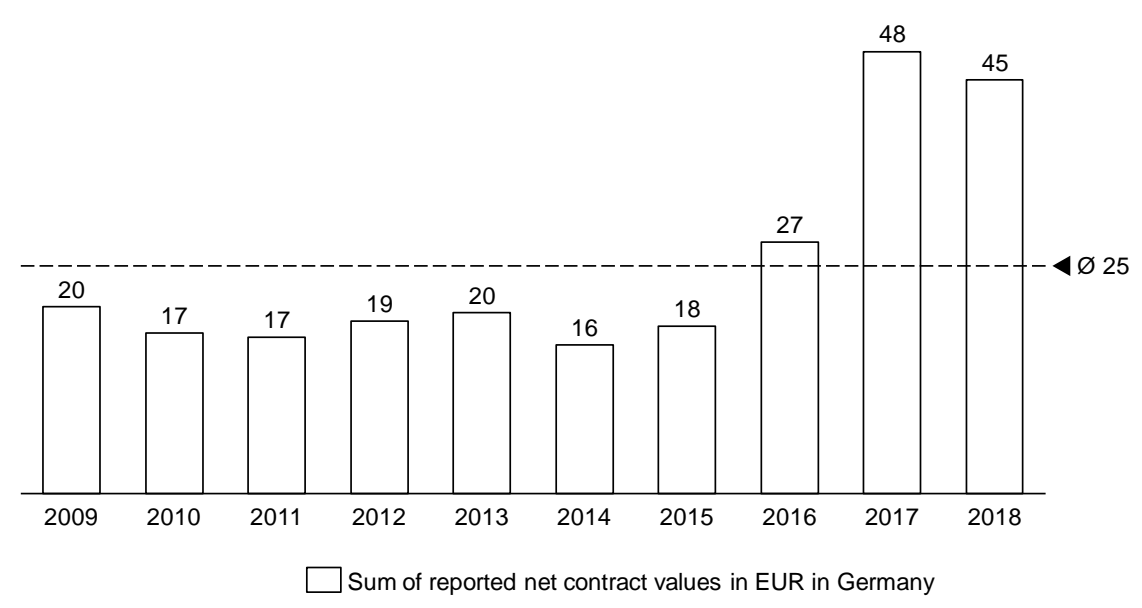

Figure 1: Total net contract value in billions of euros for Germany only

This positive development in the number and volume of public contracts contrasts with the negative trend in the number of bidders, which has been observed for years. In 2009, an average of nine offers were received for a tendered lot, while in 2014 an average of six offers were received. The more recent figures from 2017 and 2018 demonstrate that this trend has continued. The average number of current bids is about four (see Figure 3).

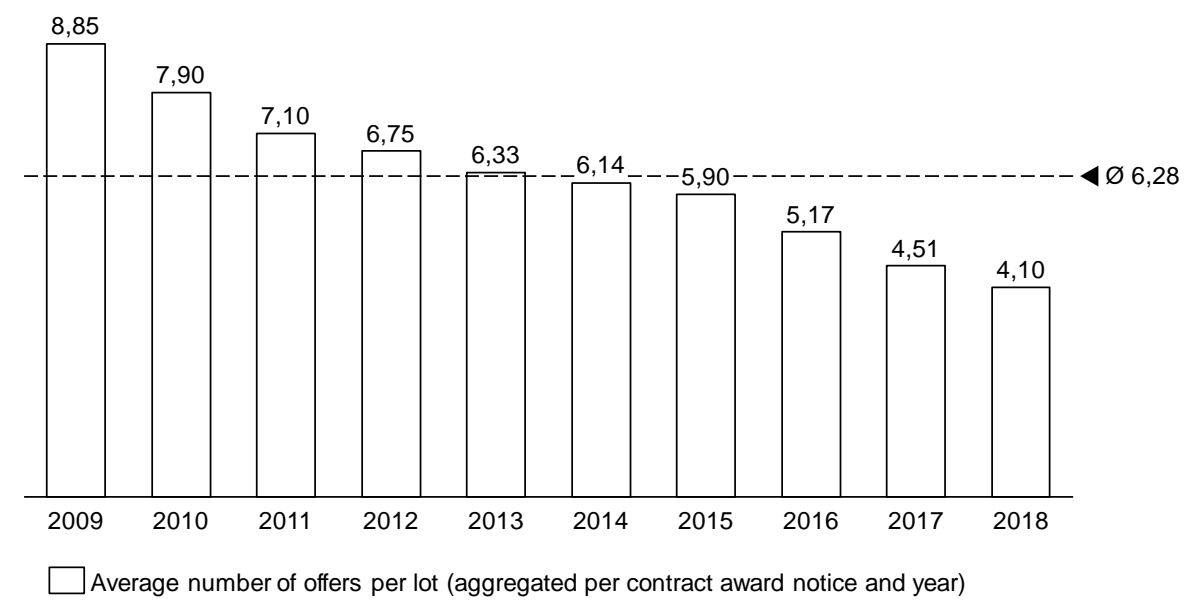

Figure 2: Average number of offers received

The number of lots for which only a single offer was received also increased significantly in the period between 2009 and 2018 (cf. Figure 4). Since 2016, the upward trend has been especially clear. In fact, in 2018, despite the broadest possible tendering behavior across Europe, only one bid was received for more than $20 \%$ of all public procurement contracts. Considering the strong economic situation in Germany before the crisis (cf. Figure 4), this initially seems to imply that, from the bidders' point of view, winning public contracts is unattractive. 


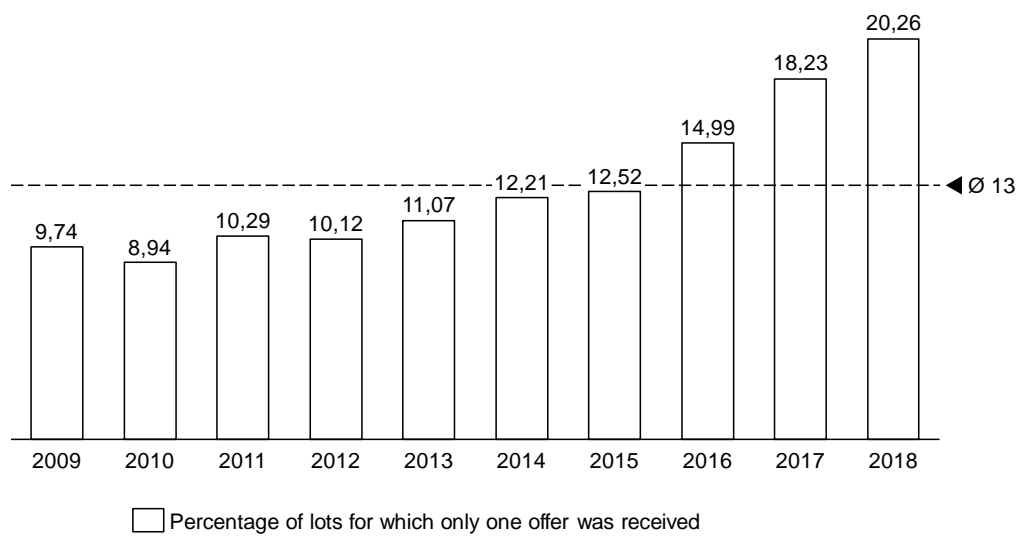

Figure 3: Share of lots with only one offer received in \%

The data on the public procurement behavior reveals the following (Findings II from the secondary analysis of the TED:

a) The number of published CAN in the EU increased by $71 \%$ over a nine year period (2009 to 2018), and the volume of contracts awarded increased by $125 \%$ in the same period, as reflected in the TED database. Even if these data only document the increasing publication activity, it can be assumed that public procurement activity has not decreased.

b) Despite rising volumes and, thus, increasing attractiveness, the number of bidders has fallen by almost $54 \%$ over the same period.

c) Apparently, it is no longer attractive for companies to bid for public contracts, and the "Public Customer Attractiveness" is low [Eßig et al., 2014].

d) These problems exist independently of peaks in demand, which typically occur in crisis situations. Despite the increasing number and volume of services put out to tender, the bidding market has becoming increasingly tighter. At the same time, supply to the public sector seems to have declined, which indicates that general signs of supply bottlenecks already existed before the crisis.

\subsection{Empirical findings III: Moving public procurement toward a supply chain perspective}

The Directive 2014/24/EU only provides limited insights into modern supply chain management. Article 58 (4) specifies that contracting authorities may impose requirements to ensure that economic operators possess the necessary human and technical resources and experience to perform the contract to an appropriate quality standard. To prove technical and professional ability, annex VII (d) specifies that it is sufficient to indicate which supply chain management and tracking systems the economic operator will apply when performing the contract. A similar view was adopted in 2016, when the public procurement directives in Germany were overhauled.

German public procurement law designates different participants in a supply chain. These include the contracting authorities (Sections 98, 99, 100 and $101 \mathrm{GWB}$ ), the main contractors (before the conclusion of the contract, the term "bidders" or "candidates" is used; after the conclusion of the contract, a distinction is made between "successful bidders" and "unsuccessful bidders," see Section $46 \mathrm{UVgO}$ ) and the subcontractors (also referred to as subcontractors or subcontractors, see Section 132 (2) No. 4 (c) GWB, Sections 8 (2) No. 5, 36, 46 (3) No. $10 \mathrm{VgV}$ and Section 26 UVgO) 
[Burgi, 2018], [Deutscher Bundestag, 2018]. From the perspective of supply chain management [Eßig et al., 2013], based on the focal organization within a supply chain (in this case the contracting authority, level 0), the direct suppliers (in this case the main contractor, level -1) and the suppliers' suppliers (in this case subcontractors, level -2) are, in principle, subject to public procurement law [Pala et al., 2014]. While the contracting authority has a direct contractual relationship with the main contractor, there is often no contractual relationship between the contracting authority and the subcontractor. Overall, the different stages of the supply chain in the procurement and award activities can be accounted for and made transparent with a proactive supply chain management and supply chain monitoring system. However, the "view" of the supply chain only extends to a maximum of level -2. All other members of the supply chain, such as those at levels -3 and -4 , remain unknown, at least from the point of view of procurement law. Moreover, the German public procurement directives allow supply chain management activities to be transferred and conducted by the main contractor. Therefore, these activities can be excluded from the responsibility of public authorities.

A transparent view of the entire supply chain helps clarify how all or selected important components of a contract item are brought together and made available through the various stages of the supply chain to form a comprehensive supply item. If the supply chain is not transparent, it is difficult to identify risks, disruptions or compliance with social or environmental requirements along the value chain [Fraser et al., 2020].

For example, in the automotive industry supply chain, the loss of a feed supplier in South Africa can mean that cattle can no longer be kept. This may cause a shortage of leather for seats and interiors and lead to a production standstill in the German automotive industry. At this point, it is clear that the visibility of first and second tier suppliers is insufficient. A deeper look into the structure of the supplier network is necessary to enable procurement decisions that counteract the risks of failure and supply ("multi-tier" supply chain management) [Chae et al., 2019].

Looking at the few publicly available references from public procurement officers, it can be assumed that the current view of supply chains is more focused on first level suppliers. For example, the procurement office of the Federal Ministry of the Interior, Building and Homeland Affairs (BeschA) reports that the current supplier base (main contractor) comprises a total of 465 suppliers and had an order volume of around €5.3 billion in 2019. About two-thirds of these suppliers have long-term relationships with BeschA, and the remaining one-third are new suppliers [Beschaffungsamt des Bundesministeriums des Inneren, 2020]. No information on the number of subcontractors is provided in the report. The number of main contractors from other countries is also not provided. Here, it can only be assumed on the basis of other studies in the field of cross-border procurement that very few main contractors come directly from abroad [Ramboll \& HTW Chur, 2011]. Public procurement law explicitly allows information about the supply chain management and supply chain monitoring system from the main contractor to be requested during the verification of technical and professional performance (§46 Section 3 No.4 $\mathrm{VgV})$. Ultimately, these activities could be outsourced to the main contractor, who then would have to inform the contracting authority about changes in the supply chain, at least in the security and defense sector ( $\$ 8$ Section 2 No.7 VSVgV). The following figure illustrates the above facts by outlining a supply chain, including the supplier levels. 


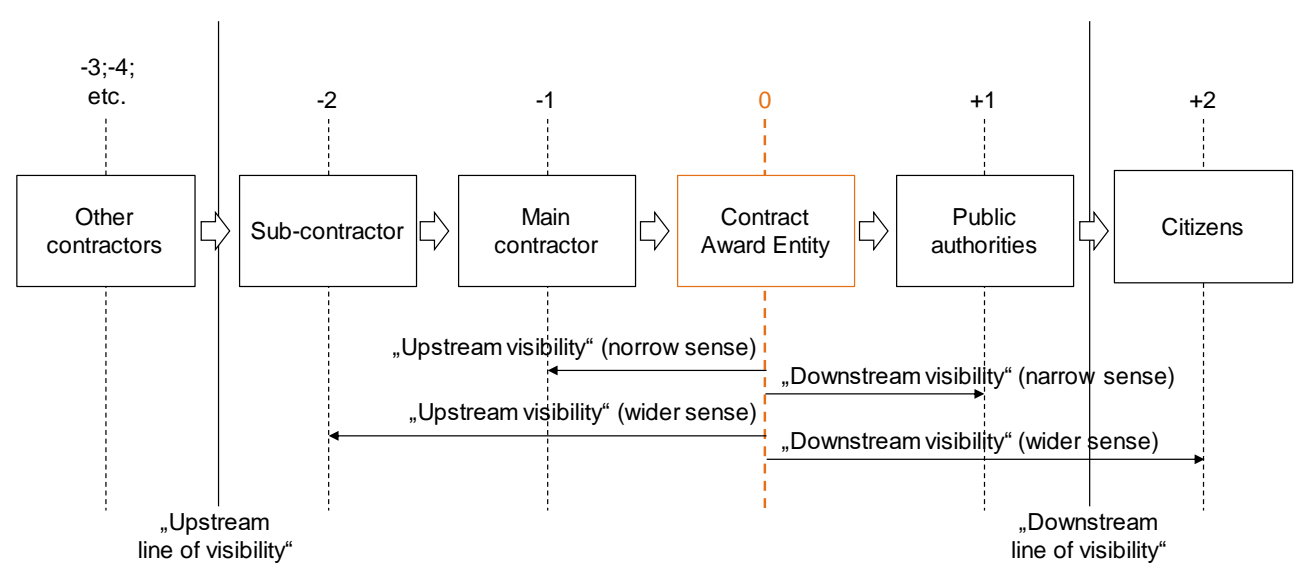

Figure 4: Sketch of a public "supply chain" 4

Supply chains can be very complex. Even the companies involved may struggle to understand them [Eßig et al., 2013, pp. 33 f.; following Ostertag, 2008, p. 287]. However, all service providers in the economy (i.e., all bidders) are highly dependent on inputs. The share of external procurement by industrial companies is usually well over $50 \%$ of turnover; in individual cases, it is considerably higher (e.g., Volkswagen is approximately 75\%). The entire supply chain of an organization can take on enormous proportions. For example, in a recent press release, Volkswagen mentions 40,000 suppliers who must be addressed in more than 19 national languages [VW AG, 2020]. In Finland's blood donation supply chain, 210,000 "suppliers" are connected to 100,000 "customers" through three stages, involving more than 100 participating organizations [Eßig et al., 2013, pp. 33 f.; following Spens \& Bask, 2002, p. 77].

Findings III from the view of the supply chain:

a) In supply chains with a complex division of labor, procurement and supply risks arise from the supplier's direct source of supply and primarily at upstream stages of the value chain.

b) Currently, the public sector can establish a certain transparency in public procurement law down to the subcontractor (supplier of the supplier, level -02).

c) If public procurement is still limited in its risk assessment to first-tier suppliers when making award decisions, significant parts of the supply chain are ignored and risk management is incomplete.

\section{A competency-based approach for public procurement: Three theses}

The empirical findings demonstrate that the COVID-19 crisis acts like a burning glass on the status of procurement in the public sector. Although there was an obvious problem with protective gear, security of supply seems to be a general problem. The bidding behavior of suppliers and the supply chain perspective indicate that addressing only the crisis is insufficient. Instead, further development of public procurement needs to address the underlying causes of these problems. Using a competency-based approach, this article formulates three theses that address the development of professional, evidence and technology competencies.

${ }^{4}$ Adopted from Eßig/Batran (2006) 


\subsection{Thesis (1): Competencies of public buyers: Toward a recognized „profession“}

The empirical findings indicate that the skills of public buyers must be better promoted and utilized in the future. The developments in the COVID-19 crisis have revealed that, in addition to the basic principles of procurement law, employees and managers in strategically oriented public purchasing fields require specific competencies in exchange with the procurement markets. For example, they must be able to observe and analyze markets and competitive situations over the long term in order to initiate the search for substitutes or supplementary suppliers with sufficient time (e.g., in the event of bottlenecks or delays). Therefore, the required spectrum of necessary competencies should be identified specifically for the public sector and implemented with the appropriate focus on education, training and continuing education programs. These programs should be of particular interest if successful participation with officially recognized qualifications opens up career prospects in public procurement.

Indeed, in October 2017, before the COVID-19 crisis, the European Commission called for further professionalization of public procurement in the member states [European Commission, 2017a, p. 9]. The demand for the "right people with the right skills and instruments in the right place at the right time" [European Commission, 2017a, p. 11] may have been considered abstract at the time. However, the "European Competency Framework for Public Procurement Professionals" has since developed a more distinct view of the required skills. The EU Commission's proposal released in December 2020 comprises a catalog of 30 capabilities [European Commission, 2020a] that are roughly oriented toward the phases of the procurement process and the tasks specific to each phase. For example, it provides for skills that are considered relevant for public purchasers before (e.g., market analysis) and after the contract award (e.g., conflict management). In addition, there are phase-independent skills (e.g., supplier management or project management) and social/methodological skills (e.g., critical and analytical thinking and acting) that will be required of future public purchasers.

Three essential bundles of skills stand out from the 30 skills listed. Targeted training in these areas could contribute to building up and expanding the skills that have become relevant in the current crisis. These include (1) a better understanding of procurement markets [European Commission, 2020a, p. 44 f.]; (2) a more active supplier management system [European Commission, 2020a, p. 41 f.] and (3) dealing with digital opportunities in public procurement [European Commission, 2020a, p. 35 f.]. An improved understanding of procurement markets is related to the requirement to develop relevant knowledge about particularly critical procurement markets. On the one hand, this requires in-depth market analyses and market forecasts. On the other hand, it involves proactively addressing market participants in legally compliant ways (e.g., in the context of market dialogues, market consultations or organizing open days). A more active supplier management system includes the establishment and development of trusting, open and resilient relationships. Effective risk management can be strengthened as a further necessary competence when combined with the competencies for market analysis and market approaches. The demand for significantly enhanced skills in handling digital technologies that flank the public procurement process is not new. These should go beyond those already initiated for e-tendering or electronic tendering and settlement. For example, technologies for market analysis or in the area of supplier management could be used. 
The comparison between the requirements just described and the current training landscape in Germany demonstrates that there are few offers that reflect the required skills adapted for public procurement. So far, the focus has been on questions of public procurement and budgetary laws and the associated financial and auditing laws. For example, the Federal University of Applied Sciences for Public Administration emphasizes these issues in their bachelor's of Public Administration (LL.B) [Hochschule des Bundes für öffentliche Verwaltung, 2018, p. 34 and 59] and master's of Public Administration [Hochschule des Bundes für öffentliche Verwaltung, 2019, p. 49] programs. Courses that consider the above-mentioned business management aspects of public procurement, in addition to public procurement law, have only been available for a short time at the Bundeswehr University Munich's part-time MBA in Public Management program [UniBw M, 2020]. Finally, a survey of public buyers has confirmed the lack of training and further education opportunities for business management aspects of public procurement. Of the 308 participants in the survey, approximately two-thirds said that they had not undergone specific training for their field of activity [von Deimling \& Eßig, 2020, pp. 152].

The requirements for professionalization in purchasing should also be reflected in an attractive career path and correspondingly attractive salary ranges. A survey of 638 interviewed buyers in the private sector in Germany revealed a median gross salary of $€ 67,600$. A closer examination of the results determined an average gross salary for purchasers with vocational training of $€ 64,200$. A buyer with a master's degree would be paid an average of $€ 82,800$ [BME, 2019]. In comparison, the salary bands for buyers with training in the public sector as collective agreement employees are in pay categories E6-E8 or pay grades A6-A8. Pay category E8 (TVöD Bund, experience level $4=10$ years or more in the public sector) or A8 would be around $€ 40,000$ to $€ 42,400$ (gross). As a result, there is a payment gap between public buyers and private buyers of more than $€ 21,800$ and $€ 24,200$, but public buyers often act in even more complex governance structures (law, politics, public attention) that require peculiar skills. At the management level, the gap is much smaller. Comparing the private sector payments with corresponding salaries for an E15.4/A15.4 position (just under $€ 80,000$ (gross)) result in a gap of only $€ 2,800$ yearly. Ultimately, the civil service should be prepared to offer higher pay for more professional and competent purchasers and revise the remuneration models for non-management positions like senior strategic buyers.

The call for an improved and extended use of necessary competencies in public procurement, combined with an improved education, training and continuing education landscape, will be insufficient to equip and transform public procurement with the necessary competencies in a sustainable manner. The "European Competency Framework for Public Buyers" will provide an orientation for the differentiated structuring of the necessary competencies, depending on the role and task of the public buyer. The recruitment, training and development of talents and competencies in public procurement should also be expressed in corresponding career opportunities. As in other countries (e.g., Denmark, Poland, Portugal or the Netherlands), the recognition of "public buyer" as a profession in its own right would be a useful vehicle [OECD, 2013, pp. 78].

\subsection{Thesis (2): Evidence-based decision-making}

At a European and national level, the requirement for transparency means that government action and economic decisions must be open, public and comprehensible. Transparency can be understood as a quantity of information that must be accessible to the legal entities involved. It 
should also comprehensibly and predictably present state action. Transparency aims to make the decision-making processes understandable and legitimate (participation and legitimation), control the decision-making processes and secure subjective rights (control and protection), open the decision-making processes in the award of public contracts to competition and ensure equal treatment of all legal entities involved (competition and equality). Against this background, the awarding of public contracts requires ex-post transparency (i.e., the comprehensibility of the award decision taken) and ex-ante transparency (i.e., the predictability of future award decisions). The publication of future award decisions will inform potential bidders about the procurement intentions of the contracting authorities, who will then independently decide whether to participate in the procedure [Plauth, 2017, pp. $185 \mathrm{ff}]$.

To implement the transparency requirement, information on contract notices (ex-ante), CAN (expost) and corresponding changes to the notices are published and archived on different portals and at different levels of granularity. At the European Union level, all relevant notices above defined thresholds concerning future or completed procedures are accessible via the electronic Official Journal of the European Union (Tenders Electronic Daily/TED). For example, since 2006, more than 1.7 million CAN, with more than 72 information fields per individual notice, have been archived [European Commission, 2017b] [European Union, 2019]. This enormous amount of data and the information hidden in it is gradually becoming the focus of political decision makers who want to professionalize public procurement and make decisions based on the information collected [OECD, 2019, pp. 144 f.]. For example, a "Single Market Scoreboard" has been set up to provide key figures on the development of public procurement in Europe and its member states [European Commission, 2020b]. However, these indicators are limited to contracts above the defined thresholds. Contracts below these thresholds are not recorded, and there are numerous exceptions where publicity is not required (e.g., in the security and defense sector). Moreover, the quality of the data is often questioned due to the varying degrees of precision of recording in the member states [Prier et al., 2020, p. 8 f.].

At the national level, there are also efforts to systematically collect information on procurement procedures and use it in decision-making. The aim should be to collect basic data on public contracts and concessions for Germany as comprehensively as possible. To this end, the federal government issued the Ordinance on Public Procurement Statistics (VergStatVO) in April 2016 [BMWi, 2020], which allows contracts below the thresholds, from 25,000 EUR, to be covered. In addition, data on the development of politically set objectives (e.g., on environmental sustainability) will be requested. In March 2020, an automated data collection system was set up, which will be archived and evaluated by the Federal Statistical Office. The collection of reliable data is planned for the beginning of 2021 [OECD, 2019, p. 139]. Ultimately, these notices of intention to award contracts to public authorities will establish procurement statistics for Germany, similar to the key figure reports of the European Union. The developed key figure systems on European and national levels are oriented toward political decision makers [OECD, 2013, p. 86] [ OECD, 2019, p. 142]. Currently, these systems are rarely used by the individual contracting authorities for extended decision-making. Comparative analyses with contracting authorities with a comparable portfolio of tasks (e.g., comparative analyses on the procurement of public utilities) may be possible. Market analyses of bidders in a specific product group who have already been awarded contracts by other contracting authorities (e.g., with the aim of expanding bidder lists) are also conceivable. In addition, key award parameters can be compared between 
different contracting authorities to identify bundling potential across authorities. Finally, external "data treasures" enable the individual contracting authorities to look beyond their own outfits. Therefore, the transparency requirement has advantages for potential bidders and the contracting authorities.

At the level of individual contracting authorities, data and fact-driven decision-making is also helpful. Ideally, the contracting authorities can use information from their enterprise-resourceplanning (ERP) systems. For example, they can view contract release orders by time, quantity and value, develop expenditure analyses and demand forecasts, record demand notifications and identify potential for demand pooling and carry out supplier structure analyses and creditor evaluations. This information can then be used to derive essential decisions on procurement issues and, ideally, data- and fact-based procurement strategies [OECD, 2013, pp. 107 f.]. This information, which often already exists, can be extended by new applications, such as those offered by the start-ups ScoutBee [ScoutBee, 2020] or Riskmethods [Riskmethods, 2020]. ScoutBee helps with the digital search for and evaluation of suppliers, while Riskmethods provides support for the automatic early recognition, evaluation and mitigation of risks along value chains.

The call for evidence-based decisions (i.e., decisions that are systematically based on data, facts and figures) in public procurement at all levels is not new [OECD, 2013, pp. 107 f.] [OECD, 2019, p. 141]. However, so far, efforts seem to have focused on the question of which data to collect for each procurement and award project. Accordingly, it can be observed that large amounts of data are already being recorded and archived [Glas \& EBig, 2018]. Almost reflexively, the quality of these data volumes, or "data treasures," which have been collected at great expense, is often doubted. Moreover, the data has not been adequately interrogated to determine its potential. Although these doubts are justified and data quality must be improved, these concerns should not distract from the central question of what data is actually needed and can be sensibly used for specific decisions at various decision-making levels. For example, at the level of the individual contracting authority, it is necessary to combine different external and internal information and utilize additional information from available applications. The work with the data cannot be carried out as a side job in conjunction with other tasks in public procurement. It requires the development and expansion of its own analytical capacities and competencies (e.g., in the form of data specialists with expert knowledge of purchasing).

\subsection{Thesis (3): Using digital technologies to improve security of supply}

Even in times of crisis and under adverse circumstances, businesses and citizens rely on the government to perform its tasks reliably. The sometimes short-term changes in a crisis situation pose enormous challenges for public clients. For example, short-term supply bottlenecks, shortterm peaks in demand and disruption of entire supply chains must be responded to appropriately and quickly. Against this background, it necessary to establish a reliable risk management system for the early identification of risks and promote an understanding of supply chain considerations (i.e., supply chain management) [Kleindorfer \& Saad, 2010]. It is also imperative to question the use of new technologies and production processes in the context of the government's performance of its tasks. Especially in the event of a crisis, it is important to have a high degree of flexibility to be able to react as quickly as possible to uncertainties and guarantee the efficiency of the state. In this context, flexibility can be understood as the efficient and effective adjustment and 
reconfiguration of production factors. In this respect, it is conceivable to use additive manufacturing processes to ensure flexibility and responsiveness [Caviezel et al., 2017, pp. 1-27].

Additive manufacturing ("3D printing") uses a digital representation (CAD file) of the object to be manufactured, then the corresponding source materials are positioned and joined together layer by layer until a physical image is created [Ghadge et al., 2018]. Due to "tool-less" manufacturing [Holmström \& Partanen, 2010], a 3D printer can handle a wide range of different materials [Rogers et al., 2016] and a variety of designs with different degrees of complexity [Ghadge et al., 2018]. The physical starting materials consist of raw materials like powder and filament. They are highly unspecific and are increasingly becoming a standard commodity [Öberg, 2019]. The fully automated manufacturing process also requires almost no monitoring [De La Torre et al., 2016]. This indicates that the technology has found its way into the so-called maker movement, in which hobbyists independently design and manufacture products [Waller \& Fawcett, 2014]. Virtual drawing data are key factors. These can be easily created, modified and exchanged [Oettmeier \& Hofmann, 2016] because their standardized format can be read by all 3D printers (STL) [Potter \& Eyers, 2015]. Ultimately, 3D printing offers the advantage of being able to produce a wide range of different products on the same system, based on standardized raw materials and quickly available digital blueprints. The construction of specific production facilities at one location, which is time and cost intensive, can be avoided by using decentralized printer capacities. This high flexibility potential is countered by problems that still have to be overcome. For example, the current state of additive manufacturing has a cost advantage over traditional manufacturing methods, such as injection molding for small production quantities. However, additive manufacturing has so far only been used sporadically in medium and large industrial production series [Rylands et al., 2016]. Moreover, how certified drawing data sets and construction plans can be safely realized in the application must be clarified; in principle, anyone can create and distribute them.

Against this background, the state must assess how it intends to make such technological developments useful for its future tasks [Meyer et al., 2020]. Apart from a political-normative objective on the basic scope of the state's tasks and the definition of the extent to which the state is to perform its tasks, it is necessary to determine what proportion of value creation is to be performed by the state. For example, in the context of risk prevention, it is conceivable to establish and operate state-owned printing capacities and storage capacities for the required raw materials. Risk prevention through using the capacities of external third parties is also plausible. In the latter case, the aim must be to secure and make available the capacities of external third parties, especially in the event of a crisis.

The call for improved responsiveness to short-term bottlenecks and peaks in demand requires the ongoing assessment of new technologies and their range of applications. One of these promising technologies is additive manufacturing. It offers high flexibility because a wide range of different products with a variety of designs can be manufactured in the same plant, using the same standardized starting materials. Digital blueprints can be distributed quickly and implemented on available printers at different locations without having to set up special production facilities. Against this backdrop, the question arises of whether entities should set up their own 3D printer capacities and warehouses for the source components as part of government risk provisioning, or whether they should commission external service providers to provide the necessary capacity. 
Appropriate competencies for the classification of new technologies in public procurement and their meaningful use for the performance of public tasks would have to be developed more intensively, including appropriate competencies for increasing the acceptance of new technologies.

\section{Conclusion and outlook}

The COVID-19 crisis has presented new challenges to the field of public procurement. This crisis has clarified that societies rely on a professional and powerful public administration. The perception of how public procurement has managed the crisis is not entirely favorable. Therefore, public procurement improvements should be addressed with a competency-based approach. This paper argues for better collaboration between the public and private sectors, which will improve the supply security and state performance. The interface with the public sector has to be managed professionally, and public procurement has to become strategic. This implies that appropriate management skills must be developed. These skills must go far beyond an oversimplified transfer of private sector management knowledge, but must aim to a peculiar, own strategic management expertise of the public sector. So far, strategic public procurement has been mainly associated with strategic goals like green public procurement, social public procurement or public procurement that promotes innovation ("strategy content"). In the future, this must be combined with strategic processing skills like improved market exploration, supply chain risk management and explicitly formulated strategy content. The EU competency framework could form the basis for a strategy implementation of these competencies. However, further research is required to elaborate on and analyze the proposed competency-based approach. This will also help overcome the major limitation of this research: the normative reasoning and selective sampling of phenomena. 


\section{References}

[Beschaffungsamt des Bundesministeriums des Inneren, 2020] Beschaffungsamt des Bundesministeriums des Inneren (2020), Das Beschaffungsamt - Daten und Fakten, Retrieved June 17, 2020, from http://www.bescha.bund.de/DE/DasBeschA/DatenFakten/node.html

[BMWi, 2020] Bundesministerium für Wirtschaft und Energie (BMWi) (2020), Vergabestatistik: Aufbau einer bundesweiten elektronischen Vergabestatistik, Retrieved June 16, 2020, from https://www.bmwi.de/Redaktion/DE/Artikel/Wirtschaft/vergabestatistik.html

[Burgi, 2018] Burgi, M. (2018), Vergaberecht: Systematische Darstellung für Praxis und Ausbildung, 2. Auflage, München 2018, S. 109.

[Caviezel et al., 2017] Caviezel, C. \& Grünwald, R. \& Ehrenberg-Silies, S. \& Kind, S. (2017), Additive Fertigungsverfahren (3-D-Druck): Innovationsanalyse, in: Büro für TechnikfolgenAbschätzung beim Deutschen Bundestag, Arbeitsbericht Nr. 175, 2017, pp. 1-248.

[Chae et al.,2019] Chae, S. \& Lawson, B. \& Kull, T.J. \& Choi, T. (2019), To insource or outsource the sourcing? A behavioral investigation of the multi-tier sourcing decision, in: International Journal of Operations and Production Management, 39(3), 2019, pp. 385-405.

[De La Torre et al., 2016] De La Torre, N. \& Espinosa, M.M. \& Domínguez, M. (2016), Rapid prototyping in humanitarian aid to manufacture last mile vehicles spare parts: An implementation plan, in: Hum Factors Ergon Manuf, 26, 2016, pp. 533-540.

[Deutscher Bundestag, 2018].Deutscher Bundestag (2018), Beauftragung von Subunternehmern - vergaberechtlicher Rahmen, in: WD 7-3000-242/18, Dezember, 2018, pp. 1-18.

[Eßig et al., 2014].Eßig, M. \& Amann, M. \& Seifert, M. \& Steinke, A. (2014), Public Customer Attractiveness: Ist die öffentliche Hand ein attraktiver Auftraggeber? Analyse der Situation (potenzieller) Lieferanten für öffentliche Aufträge, 2014, pp. 1-22.

[Eßig et al.,2013], Eßig, M. \& Hofmann, E. \& Stölzle, W. (2013), Supply Chain Management, München 2013, S. 5.

[Eßig \& Schaupp, 2016] Eßig, M. \& Schaupp, M. (2016), Ermittlung des innovationsrelevanten Beschaffungsvolumens des öffentlichen Sektors als Grundlage für eine innovative öffentliche Beschaffung, 2016, pp. 1-74.

[European Commission, 2017a] European Commission (2017a), Eine funktionierende öffentliche Auftragsvergabe in und für Europa, in: COM(2017)572, Oktober, 2017, pp. 1-18.

[European Commission, 2017b] European Commission (2017b), TED CSV open data: Advanced notes on methodology, in: Advanced notes on methodology Version 0.9, 2017-07-14, 2017, pp. 115.

[European Union, 2019] European Union (2019), Tenders Electronic Daily (TED) (csv subset) public procurement notices, Retrieved March 6, 2019, from http://data.europa.eu/euodp/de/data/dataset/ted-csv

[European Commission, 2020a] European Commission (2020a), ProcurCompEU European Competency Framework for Public Procurement Professionals, Publications Office of the European Union, Luxembourg, 2020. 
[European Commission, 2020b] European Commission (2020b), Single Market Scoreboard, Retrieved June 16, 2020, from https://ec.europa.eu/internal_market/ scoreboard/

[Fraser et al., 2020] Fraser, I.J. \& Müller, M. \& Schwarzkopf, J. (2020), Transparency for MultiTier Sustainable Supply Chain Management: A Case Study of a Multi-tier Transparency Approach for SSCM in the Automotive Industry, in: Sustainability, 2020, pp. 14-17.

[Ghadge et al., 2018] Ghadge, A. \& Karantoni, G. \& Chaudhuri, A. \& Srinivasan, A. (2018), Impact of additive manufacturing on aircraft supply chain performance: A system dynamics approach, in: Journal of Manufacturing Technology Management, 29, 2018, pp. 846-865.

[Glas \& Eßig, 2018] Glas, A.H. \& Eßig, M. (2018), Factors that influence the success of small and medium-sized suppliers in public procurement: evidence from a centralized agency in Germany, in: Supply Chain Management: An international Journal, 23(1), pp. 65-78.

[Hochschule des Bundes für öffentliche Verwaltung, 2019, p. 49] Hochschule des Bundes für öffentliche Verwaltung (2019), Modulhandbuch 2019: Master of Public Administration, 2019, pp. $1-93$.

[Hochschule des Bundes für öffentliche Verwaltung, 2018, p. 34 and 59] Hochschule des Bundes für öffentliche Verwaltung, F.B. (2018), Modulhandbuch, Studiengang: Bachelor of Public Administration (LL.B.), February, 2018, pp. 1-76.

[Holmström \& Partanen, 2010] Holmström, J. \& Partanen, J. (2010), Rapid manufacturing in the spare parts supply chain, in: Journal of Manufacturing Technology Management, 21, 2010, pp. $687-697$.

[Kleindorfer \& Saad, 2010] Kleindorfer, P.R. \& Saad, G.H. (2010), Managing disruption risks in supply chain, in: Production and Operations Management, 14(1), 2010, pp. 53-68.

[Meyer et al., 2020] Meyer, M.M. \& Glas, A.H. \& Eßig, M. (2020), Der Einfluss additiver Fertigung auf Operational Performance: Lieferkettenmodellierung am Fallbeispiel einer globalen Einsatzorganisation, in: Controlling, Zeitschrift für erfolgsorientierte Unternehmenssteuerung, 32(3), pp. 14-21.

[Öberg, 2019] Öberg, C. (2019), Additive manufacturing - digitally changing the global business landscape, in: European Journal of Management and Business Economics, 28(2), 2019, pp. 174188.

[OECD, 2013, p. 78 ff.] OECD (2013), Implementing the OECD Principles for Integrity in Public Procurement Progress since 2008, in: OECD Public Governance Reviews, 2013, pp. 1-136.

[OECD, 2019, pp. 144-145] OECD (2019), Public Procurement in Germany: Strategic Dimensions for Well-being and Growth, in: OECD Public Governance Reviews, 2019, pp. 1-254.

[Oettmeier \& Hofmann, 2016] Oettmeier, K. \& Hofmann, E. (2016), Impact of additive manufacturing technology adoption on supply chain management processes and components, in: Journal of Manufacturing Technology Management, 27, 2016, pp. 944-968.

[Pala et al.,2014].Pala, M. \& Edum-Fotwe, F. \& Ruikar, K. \& Doughty, N. et al. (2014), Contractor practices for managing extended supply chain tiers, in: Supply Chain Management, 19(1), 2014, pp. 31-45. 
[Plauth, 2017, p. 185 ff] Plauth, M. (2017), Die Rechtspflicht zur Transparenz im europäisierten Vergaberecht: Eine Grundlage zur rechtssicheren Anwendung des vergaberechtlichen Transparenzgrundsatzes., ed., Köln 2017.

[Potter \& Eyers, 2015] Potter, A.T. \& Eyers, D.R. (2015), E-commerce channels for additive manufacturing: an exploratory study, in: Journal of Manufacturing Technology Management, 26, 2015, pp. 390-411.

PriceWaterhouseCoopers (2020), Erleichterte Beschaffungsregelungen im Zusammenhang mit der Corona-Pandemie, April, 2020.

[Prier et al., 2020, p. 8 f.] Prier, E. \& McCue, C.P. \& Csaki, C. (2020), Evaluating Decision Speed as a Measure of Public Procurement Performance in the European Single Market, in: International Journal of Public Administration, 2020, pp. 1-11.

[Ramboll \& HTW Chur, 2011] Ramboll \& HTW Chur (2011), Cross-border Procurement Above EU Thresholds, in: European Commission, DG Internal Market and Services(March), 2011, pp. 1154.

[Riskmethods, 2020] Riskmethods (2020), Risikomanagement für Ihre Lieferkette, Retrieved June 16, 2020. From https://www.riskmethods.net/de/

[Rogers et al., 2016] Rogers, H. \& Baricz, N. \& Pawar, K.S. (2016), 3D printing services: classification, supply chain implications and research agenda, in: International Journal of Physical Distribution \& Logistics Management, 46, 2016, pp. 886-907.

[Rylands et al., 2016] Rylands, B. \& Böhme, T. \& Gorkin, R. \& Fan, J. et al. (2016), The adoption process and impact of additive manufacturing on manufacturing systems, in: Journal of Manufacturing Technology Management, 27, 2016, pp. 969-989.

[ScoutBee, 2020] ScoutBee (2020), Smarte Lieferantensuche, Retrieved June 16, 2020, from https://scoutbee.com/de/

[UniBw M, 2020] UniBw M (2020), MBA Public Management, Retrieved June 16, 2020, from https://www.unibw.de/casc/programme/mba-public-management

[von Deimling \& Eßig, 2020, pp. 152 f.] von Deimling, C. \& Eßig, M. (2020), Innovative öffentliche Beschaffung: Konzeption und Implementierung, in: Klipstein, C. \& Antan ( Eds.), E-Vergabe, Grundbegriffe-Schnittstellen-Fehlerquellen, Köln 2020, pp. 135-158.

[VW AG, 2020] VW AG (2020), Volkswagen unterstützt seine 40.000 Lieferanten mit Anleitung für Schutzmaßnahmen in der Produktion, Retrieved June 17, 2020, from https://www.volkswagen-newsroom.com/de/pressemitteilungen/volkswagen-unterstuetzt-seine40000-lieferanten-mit-anleitung-fuer-schutzmassnahmen-in-der-produktion-5979

[Waller \& Fawcett, 2014] Waller, M.A. \& Fawcett, S.E. (2014), Click Here to Print a Maker Movement Supply Chain: How Invention and Entrepreneurship Will Disrupt Supply Chain Design, in: Journal of Business Logistics, 35, 2014, pp. 99-102. 